\title{
Mineralogy and Geochemistry of Kimberlites and Related Rocks from Finland
}

O'Brien $^{1}$, H.E. and Tyni ${ }^{1}, M$.

1. Geological Survey of Finland, P.O. Box 96, FIN-02151 Espoo, Finland (hugh.obrien@gsf.fi; matti.tyni@gsf.fi)

\section{Introduction}

In January 1997 the Geological Survey of Finland initiated a study of Finnish kimberlitic intrusions discovered by Malmikaivos Oy as a result of their diamond exploration activities (Griffin et al., 1995; Tyni, 1997). These Paleozoic intrusions (two pipes dated by K-Ar gave 590 and $430 \mathrm{Ma}$ ) form the Eastern Finland Kimberlite Province which includes the Kaavi and Kuopio clusters. The pipes and dikes intruded into 3.1-2.6 Ga gneiss complexes of the Archean Karelian craton and allochthonous 1.9 - $1.8 \mathrm{Ga}$ metasedimentary cover rocks thrust onto the craton during the Svecofennian orogeny. The intrusions are dominated by textural and mineralogical variants of archetypal kimberlites but also include less common dikes of ultramafic lamprophyre and olivine lamproite. Ranging from purely hypabyssal kimberlite dikes to multiphase pipes of diatreme facies volcaniclastics, the Finnish kimberlites generally contain abundant diamond indicator minerals and almost all contain at least trace amounts of microdiamonds. Of the 24 intrusive bodies discovered, we have drill core samples from 12 (Table 1) from which 30 samples have been analyzed for major and trace elements and $14 \mathrm{for} \mathrm{Sr}$, $\mathrm{Nd}$ and $\mathrm{Pb}$ isotopic compositions.

\section{Sample Description and Mineralogy}

Pipe 1 was discovered by Malmikaivos Oy in 1964 (Tyni, 1997) and is the only sample in our collection that may represent a magma composition although cumulate oribicules indicate that some crystal accumulation occurred. It is an aphanitic spinel-rich monticellite kimberlite (Table 1) with a small volume marginal phase of carbonate-rich kimberlite. Containing up to $40 \%$ olivine as macrocrysts and phenocrysts in a matrix of monticellite microphenocrysts, perovskite, spectacular atoll spinels zoned from chromite to magnesian ulvöspinel, serpentine and calcite, the main phase of the pipe is mostly massive but about $10 \%$ has a carbonate segregation-texture. Cemented into the carbonate matrix ( $25 \%$ by volume) of the marginal phase rocks are globular segregations of aphanitic silicate kimberlite magma and olivine-pseudomorphs surrounded by a thin veneer of silicate magma. Pipes $2 \& 3$ occur near each other (within $500 \mathrm{~m}$ ), are both elongate bodies and both contain the same volcaniclastic and hypabyssal rocks with serpentine pseudomorphs after olivine macrocrysts in a matrix of perovskite, serpentine and calcite. Exceptional volcaniclastic breccias from pipe 3 contain abundant xenoliths of quartzite, gneisses and granitoids. Pipes $4 \& 6$ are composed exclusively of diatreme facies volcaniclastic breccias, which have been considerably altered to clay minerals. Nevertheless some garnet-bearing peridotite xenoliths have survived the alteration process mostly intact. Pipe 5 contains serpentinized olivine macrocryst-rich hypabyssal kimberlite and volcaniclastic diatreme facies rocks that vary from breccias to ash-rich sandstones. It is unclear whether the sandstones represent resedimented material from the very top of a diatreme or simply more completely comminuted material. The hypabyssal rocks contain relatively fresh garnetbearing peridotite xenoliths. Pipe 9 contains hypabyssal kimberlite rich in olivine and picroilmenite macrocrysts and garnet-bearing peridotites (mostly lherzolite). Pipe 10 is a multiphase pipe dominated by picroilmenite-rich volcaniclastic breccia studded with about $5 \%$ subrounded autoliths of dark gray hypabyssal material that likely represent samples of a magmatic phase. The diatreme 
rocks contain olivine pseudomorphs, picroilmenite, garnet and Cr-diopside macrocrysts and relatively abundant peridotite and eclogite xenoliths in an opaque-rich, serpentine-calcite matrix. Pipe 14 contains fresh olivine and picroilmenite macrocrystic hypabyssal kimberlite and kimberlite breccia. The breccia in places is rich in crustal xenoliths, however, other parts have dominant peridotite xenoliths or are crystallinoclastic comprising essentially disaggregated peridotite minerals in minimal kimberlite matrix. Ultramafic lamprophyre dike 15 is composed mostly of large serpentine pseudomorphs (after olivine?), zoned phlogopite, and carbonate with accessory ilmenite, titanomagnetite, rutile and apatite. Lamproite dike 16 is composed largely of phlogopite and pseudomorphs of olivine and is intriguing because it appears to have some affinities to Type II kimberlites (orangeites in the terminology of Mitchell, 1995). The sample contains grains of a calcium zirconium silicate (Ca-catapleite?) rather than the lamproite typomorphic mineral wadeite and zoning in micas that follow the extreme $\mathrm{Al}$ depletion evolutionary trend diagnostic of orangeite micas. However the mica core compositions have relatively high $\mathrm{Ti}$; within the field demarcated as lamproite by Mitchell (op. cit.) and the major element composition of the sample is nearly exactly equivalent to the average for olivine lamproite calculated by Mitchell and Bergman (1991). Pipe 23 is composed exclusively of volcaniclastic kimberlite breccia and contains the least altered diatreme material of any of the pipes sampled. This rock has approximately $25 \%$ crustal and mantle xenoliths and $<5 \%$ rounded autoliths contained in a matrix that has a distinctly blue color.

Table 1. Characteristics of Finnish Kimberlites and Related Rocks

\begin{tabular}{|c|c|c|c|c|}
\hline $\begin{array}{l}\text { Pipe / } \\
\text { Dike }\end{array}$ & Shape & Size (m) & $\begin{array}{l}\text { Dominant } \\
\text { Rock Type }\end{array}$ & Mineralogy \\
\hline$\# 1$ & oval pipe & $110 \times 150$ & $\begin{array}{l}\text { chrome spinel-rich hypabyssal } \\
\text { monticellite kimberlite }\end{array}$ & $\begin{array}{l}\text { olivine, monticellite, spinel, } \\
\text { perovskite, serp, cc }\end{array}$ \\
\hline$\# 2$ & elongate pipe & $300 \times 20-40$ & $\begin{array}{l}\text { hypabyssal kimberlite breccia > } \\
\text { volcaniclastic kimberlite breccia }\end{array}$ & serp-ol, cc, serp, perovskite \\
\hline$\# 3$ & elongate pipe & $250 \times 40$ & $\begin{array}{l}\text { hypabyssal kimberlite breccia > } \\
\text { volcaniclastic kimberlite breccia }\end{array}$ & serp-ol cc, serp, perovskite \\
\hline$\# 4$ & double pipe & $150 \times 100$ & $\begin{array}{l}\text { volcaniclastic kimberlite breccia } \\
\text { only }\end{array}$ & serp-ol, clay-rich in matrix \\
\hline$\# 5$ & $\begin{array}{l}\text { dike with breccia } \\
\text { (blows?) at each end }\end{array}$ & $>500 \times 20$ & $\begin{array}{l}\text { macrocryst-rich hyp kimb>vol } \\
\text { kimb, some finely comminuted }\end{array}$ & $\begin{array}{l}\text { olivine, serp, cc, peridotite } \\
\text { fragments }\end{array}$ \\
\hline$\# 6$ & irregular elongate pipe & $200 \times 70$ & $\begin{array}{l}\text { volcaniclastic kimberlite breccia } \\
\gg \text { hypabyssal kimberlite breccia }\end{array}$ & serp-ol, clay-rich matrix \\
\hline$\# 9$ & irregular oblate pipe & $100 \times 50$ & $\begin{array}{l}\text { macrocrystic hypabyssal kim- } \\
\text { berlite }\end{array}$ & $\begin{array}{l}\text { olivine, } \mathrm{Mg} \text {-il-rich, serp, cc, } \\
\text { peridotite fragments }\end{array}$ \\
\hline$\# 10$ & $\begin{array}{l}\text { irregular oblate, hyp } \\
\text { kimberlite limited to } \\
\text { one end of pipe }\end{array}$ & $150 \times 200$ & $\begin{array}{l}\text { macrocryst-rich volcaniclastic } \\
\text { kimberlite br }>\text { macrocryst-rich } \\
\text { hypabyssal kimberlite breccia }\end{array}$ & $\begin{array}{l}\text { serp-ol, Mg-il-, pyrope-, Cr- } \\
\text { diopside-rich, serp, cc, spinel, } \\
\text { peridotite \& eclogite fragments }\end{array}$ \\
\hline$\# 14$ & irregular oblate pipe & $100 \times 50$ & $\begin{array}{l}\text { hypabyssal kimberlite }>\text { hy- } \\
\text { pabyssal kimberlite breccia }\end{array}$ & $\begin{array}{l}\text { serp-ol, Mg-il-rich, serp, cc, } \\
\text { abundant peridotite fragments }\end{array}$ \\
\hline$\# 15$ & dike & $\begin{array}{l}2 \mathrm{~m} \text { wide and } \\
\text { roughly } 1 \mathrm{~km} \\
\text { long }\end{array}$ & $\begin{array}{l}\text { ultramafic lamprophyre (Ail- } \\
\text { likite) }\end{array}$ & $\begin{array}{l}\text { serp-ol, phlogopite, carbonate, } \\
\text { Mg-Mn ilmenite, Ti-magnetite, } \\
\text { rutile, perovskite, apatite }\end{array}$ \\
\hline$\# 16$ & dike & $\begin{array}{l}<5 \mathrm{~m} \text { wide, } \\
\text { length un- } \\
\text { known }\end{array}$ & olivine lamproite & $\begin{array}{l}\text { phlogopite, serp-ol, K- } \\
\text { richterite, diopside, perovskite, } \\
\text { chromite, apatite, Ca-catapleite }\end{array}$ \\
\hline$\# 23$ & oblate pipe & $80 \times 40$ & volcaniclastic kimberlite breccia & $\begin{array}{l}\text { olivine, serp, cc, peridotite } \\
\text { fragments }\end{array}$ \\
\hline \multicolumn{3}{|l|}{ KEY: } & $\begin{array}{l}\mathrm{br}=\text { breccia } \\
\text { hyp = hypabyssal } \\
\text { kimb = kimberlite }\end{array}$ & $\begin{array}{l}\text { serp-ol=serpentinized olivine } \\
\text { Mg-il=magnesian ilmenite } \\
\text { serp=serpentine, cc=calcite }\end{array}$ \\
\hline
\end{tabular}




\section{Geochemistry}

Major elements of the Finnish kimberlites and related rocks show that the samples vary from being unaltered and uncontaminated (e.g., pipe 1) to highly altered and/or contaminated (e.g., pipes 3, 4 \& 6) with contamination index values (C.I.; Clement, 1982) ranging from 1 to 2.4, respectively.

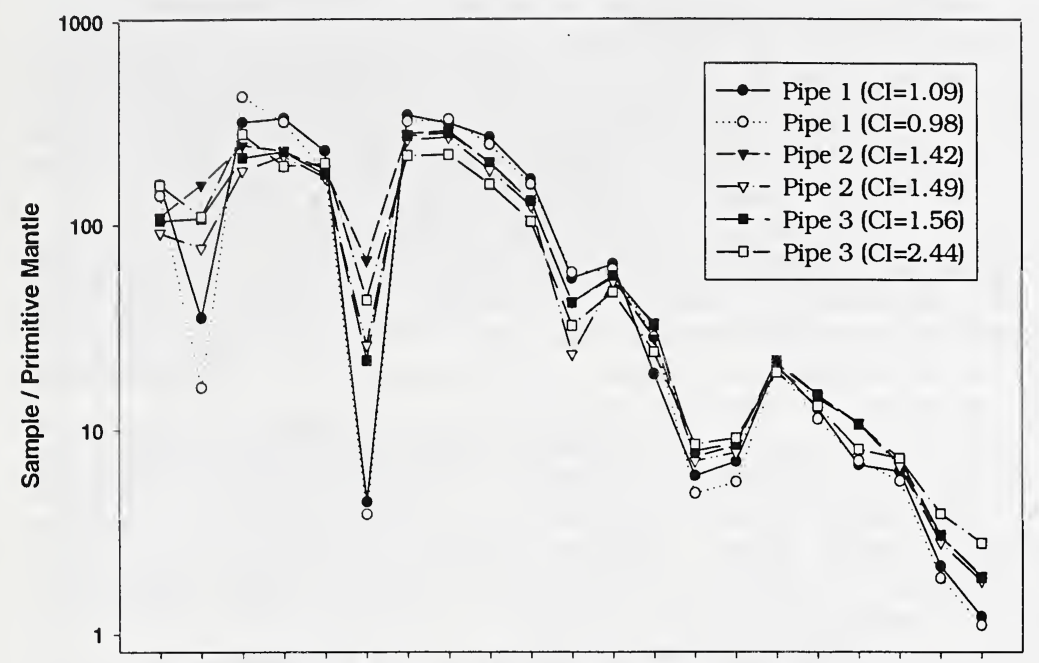

$\mathrm{Pb} \mathrm{Rb} B \mathrm{Ba} \mathrm{Th} K \mathrm{Ka}$ Nb La Ce Sr Nd P Hf Zr Sm Eu Ti Tb Y Yb

Figure 1. Primitive mantle normalized incompatible element profiles for 3 Finnish kimberlites ( $\mathrm{CI}=$ Contamination Index $)$.
Contamination vectors in an $\mathrm{Al}_{2} \mathrm{O}_{3}-\mathrm{SiO}_{2}$ diagram not unexpectedly indicate granitoid as the most significant contaminant. Yet, despite this indication for contamination, the incompatible element abundances in the Finnish kimberlites are not greatly modified relative to the pipe 1 composition (Fig. 1). This remains true even for samples with C.I. indexes as high as 2.4 where the overall effect is dilution for the elements $\mathrm{Pb}$ to $\mathrm{Nd}$ (except $\mathrm{K}$ and $\mathrm{Rb}$, Fig. 1) and enrichment in

the elements $\mathrm{P}$ to $\mathrm{Yb}$. Isotopic compositions of archetypal kimberlites have $\mathrm{Pb}-\mathrm{Nd}-\mathrm{Sr}$ compositions that appear to reflect sources in the well-mixed asthenospheric mantle and samples from Pipe 1 plot within this field, with $\varepsilon_{\mathrm{Nd}}$ of 1.4 to 1.5 and $\varepsilon_{\mathrm{Sr}}$ of -4 to -6 . Crustal contamination in the remainder of the Finnish kimberlites is manifested not such much in their Nd isotopes $\left(\varepsilon_{\mathrm{Nd}}=2\right.$ to 6$)$ but in their $\mathrm{Sr}$ isotopic compositions $\left(\varepsilon_{\mathrm{Sr}} 1.5\right.$ to 28.5$)$. The lamproite and ultramafic lamprophyre have radiogenic $\mathrm{Nd}$ and $\mathrm{Sr}$ compositions $\left(\varepsilon_{\mathrm{Nd}}\right.$ of $-15 \&-3$ and $\varepsilon_{\mathrm{Sr}}$ of $99 \& 84$, respectively) calculated at an estimated intrusion age of $450 \mathrm{Ma}$.

\section{Acknowledgments}

The authors gratefully acknowledge Ashton Mining Ltd. and Malmikaivos Oy for access to samples and exploration data and the right to publish this paper.

\section{References}

Clement, C.R., 1982, A comparative geological study of some major kimberlite pipes in the northern Cape and Orange Free State. Unpubl. Ph.D. thesis, Univ. of Cape Town.

Griffin, B.J., Rissanen, J.P., Pooley, G.D., Lee, D.C., Macdonald, I and Kinny, P.D., 1995, A new diamondiferous eclogite-bearing kimberlitic occurrence from Finland. Sixth Int. Kimb. Conf. Abs. 198-200.

Mitchell, R.H. 1995. Kimberlites, orangeites, and related rocks. New York: Plenum, 410p.

Mitchell, R.H and Bergman, S.C, 1991, Petrology of lamproites. New York:Plenum, 447p.

Tyni, M. 1997. Diamond prospecting in Finland - a review, in Papunen, H., ed., Mineral Deposits, Balkema, Rotterdam, 789-791. 